The Influence of

\title{
Aminoethoxyvinylglycine and Ethephon on Objective and Sensory Quality of 'Delicious' Apples and Apple Juice at Harvest and after Storage
}

\author{
S.R. Drake ${ }^{1}$ \\ U.S. Department of Agriculture, Agricultural Research Service, Tree Fruit \\ Research Laboratory, 1104 North Western Avenue, Wenatchee, WA 98801 \\ T.A. Eisele ${ }^{2}$ \\ Tree Top, Inc., P.O. Box 248, Selah, WA 98942 \\ M.A. Drake ${ }^{3}$ \\ Department of Food Science, North Carolina State University, Raleigh, \\ NC 27695
}

D.C. Elfving ${ }^{4}$

Washington State University, Tree Fruit Research and Extension Center, 1100 North Western Avenue, Wenatchee, WA 98801

S.L. Drake $\mathbf{5}^{5}$

Department, of Food Science, North Carolina State University, Raleigh, NC 27695

D.B. Visser $^{6}$

Washington State University, Tree Fruit Research and Extension Center, 1100 North Western Avenue, Wenatchee, WA 98801

Additional index words. Malus $\times$ domestica, growth regulators, bioregulators, fruit quality

Abstract. This study was conducted over three crop seasons using 'Delicious' (Scarletspur strain) apple trees on MM.111 rootstock. The bioregulators aminoethoxyvinylglycine (AVG) and ethephon (ETH) were applied alone or in combinations at various time intervals before harvest. Fruit response to bioregulators was evaluated at harvest and after storage. AVG applied 4 weeks before first harvest retarded starch loss at harvest, retained greater firmness, and reduced internal ethylene concentration and watercore of fruit at harvest and after both regular and controlled atmosphere storage. AVG did not influence peel color (hue values), but the flesh color of treated apples was more green. AVG in all instances tended to reduce the sensory scores for apples and apple juice. In contrast, ETH enhanced starch hydrolysis, flesh color development (green to more yellow), and soluble solids concentration while reducing titratable acidity levels. ETH had no influence on fruit firmness at harvest, but reduced firmness levels after storage in an inverse relationship to the concentration applied. Sensory values for whole apples were not influenced by ETH treatment, but ETH improved sensory preference for apple juice, particularly at early harvest. Applying AVG before ETH enhanced soluble solids and sensory scores for both fruit and juice. Treating with AVG followed by ETH at $150 \mathrm{mg} \cdot \mathrm{L}^{-1}$ permitted the maintenance of satisfactory firmness values $(>53.4 \mathrm{~N})$ after long-term storage along with better quality and sensory perceptions. Using specific combinations of both AVG and ETH permitted ETH-mediated improvements in objective and perceived fruit quality to be obtained without the losses in flesh firmness and storability due to uncontrolled ethylene evolution and ripening typically observed when ETH is applied alone preharvest.

Received for publication 13 June 2005. Accepted for publication 23 June 2005. The authors wish to express appreciation to the Washington State Tree Fruit Research Commission and Van Well Nursery for grant funds partially supporting this study and access to the orchard used for this study.

${ }^{1}$ Research horticulturist.

${ }^{2}$ Senior chemist.

${ }^{3}$ Associate professor.

${ }^{4}$ Horticulturist and professor.

${ }^{5}$ Research associate.

${ }^{6}$ Agricultural technician II.
Bioregulators can influence many important physiological processes in tree fruits when applied before harvest. Two bioregulators, aminoethoxyvinylglycine (AVG) (ReTain; Valent BioSciences, Walnut Creek, Calif.) and ethephon (ETH) (Ethrel, Bayer Crop Science, Research Triangle Park, N.C.) have been used to manipulate both tree and fruit physiological behavior(Looney, 2004). Control of vegetative growth and regulation offlowering(Elfving and Cline, 1990; Elfving et al., 2003), preharvest drop (Greene et al., 2000; Stover et al., 2003), fruit maturity (Byers, 1997; Greene, 2002; Layne et al., 2002; Stover et al., 2003; Wang and Dilley, 2001), fruit size, fruit shape, fruit color, fruit firmness, and postharvest quality (Andrews, 2001; Beaudry and Jayanty, 2003; Drake et al., 2002, 2003, 2005; Halder-Doll and Bangerth, 1987; Larrigaudiere, 1996; Watkins and Rosenberger, 1999; Wang and Dilley, 2001; Williams, 1980) have all been manipulated with the use of bioregulators. While many reports document effects on fruit quality, little information on bioregulator effects on sensory perception of fruit quality by consumers is available. One study suggests that a key factor that stimulates sales of apples is flavor (Washington Apple Commission, 2002)

Ethylene is thought to be the naturally occurring hormone that triggers fruit ripening (Blanpied, 1972). AVG inhibits ethylene biosynthesis by the fruit, thereby retarding the ripening process (Bangerth, 1978). ETH releases ethylene upon uptake by plant tissues (Yang, 1969); applying ETH to apple trees shortly before harvest can induce ethylene biosynthesis in and early ripening of fruit (Edgerton and Blanpied, 1968). However, preharvest ETH treatment also stimulates the climacteric behavior of the fruit, thereby reducing its capacity for long-term storage. Could the ethylene biosynthesis-inhibiting properties of AVG be exploited to allow brief bursts of ethylene from preharvest exogenous applications of ETH to temporarily stimulate ripening processes in apples without inducing the uncontrolled biosynthesis of ethylene in apple fruit and the accompanying loss of storability and quality? Combinations of AVG and ETH have been shown to permit better fruit color development in 'McIntosh' apple while controlling fruit ripening and maintaining fruit storability (Wang and Dilley, 2001).

The objectives of this project were 1) to evaluate the effects of AVG and ETH applied either separately or sequential trees on objective measures of fruit quality, 2) to document any effects of these bioregulators on human perceptions of sensory qualities of fresh apples or apple juice, and 3) to determine whether any bioregulator-induced improvements in sensory perception could be obtained while minimizing negative effects on storability or the incidence of fruit disorders.

\section{Materials and Methods}

This study was conducted over three crop seasons using mature 'Delicious' (Scarletspur strain) apple trees on MM.111 rootstock. Trees were located in a commercial orchard in East Wenatchee, Wash., and were planted in 1979 at a spacing of $3.3 \times 6.6 \mathrm{~m}$.

Trial 1 (2000). Applications of AVG were made to single-tree replications in five randomized complete blocks to runoffusing a hydraulic hand-gun sprayer. Trees were sprayed at 4 weeks before first (commercial) harvest $(4 \mathrm{WBH})$ with $125 \mathrm{mg} \cdot \mathrm{L}^{-1}$ a.i. AVG supplemented with $0.1 \%$ v/v SilWet surfactant (Kalo, Overland Park, Kan.). Control trees were not sprayed with either bioregulator or surfactant. 
Trial 2 (2000). Applications of ETH were made to single-tree replications in six randomized complete blocks to runoffusing a hydraulic hand-gun sprayer. Trees were sprayed at either 1 or 2 weeks before first (commercial) harvest (WBH) with either 150 or $300 \mathrm{mg} \cdot \mathrm{L}^{-1} \mathrm{ETH}$. All sprays were supplemented with $0.1 \%$ v/v Regulaid surfactant (Kalo). Control trees were not sprayed with either bioregulator or surfactant.

Trial 3 (2001). Five randomized complete blocks containing six double-tree replications each were selected from another part of the orchard that had not been previously treated with either AVG or ETH. Five double-tree replications per block (ten trees per block) were sprayed $4 \mathrm{WBH}$ with $125 \mathrm{mg} \cdot \mathrm{L}^{-1} \mathrm{AVG}$ plus $0.1 \% \mathrm{v} / \mathrm{v}$ Sylgard 309 organosilicone surfactant (Wilbur-Ellis, Fresno, Calif.) to run-off using a hydraulic hand-gun sprayer. The sixth double-tree replication in each block served as an unsprayed control. Four doubletree replications previously treated with AVG were individually sprayed to runoff using a hydraulic hand-gun sprayer with one of the following combinations of ETH and timing: ETH $150 \mathrm{mg} \cdot \mathrm{L}^{-1}$ at either $2 \mathrm{WBH}$ or $1 \mathrm{WBH}$ or ETH $300 \mathrm{mg} \cdot \mathrm{L}^{-1}$ at either $2 \mathrm{WBH}$ or 1 WBH. All ETH sprays were supplemented with $0.1 \% \mathrm{v} / \mathrm{v}$ Regulaid surfactant. Control trees were not sprayed with either bioregulator or surfactant.

Trial 4 (2002). Seven randomized complete blocks containing six four-tree replications each were selected from a part of the orchard that had not been previously treated with either AVG or ETH. Three four-tree replications per block (twelve trees per block) were sprayed $4 \mathrm{WBH}$ with $125 \mathrm{mg} \cdot \mathrm{L}^{-1}$ AVG plus $0.1 \% \mathrm{v} / \mathrm{v}$ Sylgard 309 organosilicone surfactant to runoff using a hydraulic hand-gun sprayer. One four-tree replication in each block served as an unsprayed control. The other two four-tree replications previously treated with AVG were individually sprayed with either ETH 150 $\mathrm{mg} \cdot \mathrm{L}^{-1}$ at $2 \mathrm{WBH}$ or with ETH $75 \mathrm{mg} \cdot \mathrm{L}^{-1}$ at $2 \mathrm{WBH}$ and again at $1 \mathrm{WBH}$ to runoff. The remaining two untreated four-tree replications were treated with ETH at either 75 or 150 $\mathrm{mg} \cdot \mathrm{L}^{-1}$ as described above. All ETH sprays were supplemented with $0.1 \% \mathrm{v} / \mathrm{v}$ Regulaid surfactant. Control trees were not sprayed with either bioregulator or surfactant.

Apples were harvested on two dates each year of the study corresponding to first commercial harvest and commercial harvest +2 weeks (18 Sept. and 2 Oct., 2000, Trial 2; 20 Sept. and 4 Oct., 2000, Trial 1; 10 Sept. and 24 Sept., 2001, Trial 3; 23 Sept. and 7 Oct., 2002, Trial 4). On each harvest date, 90 apples were harvested at random from each replication. Several objective fruit quality parameters, including mean sample fruit weight, flesh firmness, flesh starch content, peel and flesh color, soluble solids concentration (SSC) and titratable acidity (TA) were determined immediately on 10 fruit and 5 fruit were used to determine internal ethylene concentration (IEC) from each replication. In total, 40 fruit (20 each storage period) were placed in either regular atmosphere (RA) for $60 \mathrm{~d}$, or controlled atmosphere storage (CA),
$1.0 \% \mathrm{O}$ and $1.5 \% \mathrm{CO}_{2}$ at $1{ }^{\circ} \mathrm{C}$, for 120,150 , or $180 \mathrm{~d}$. After each storage period, fruit quality parameters were determined immediately on 10 fruit. Poststorage quality factors evaluated were firmness, peel and flesh color, SSC, TA, IEC, and visible disorders (scald, watercore, internal breakdown).

At each harvest, twenty apples selected at random from each treatment and replication were held in refrigerated storage $(<1$ month) before sensory analysis of expressed juice. Twenty additional apples from each treatment and replication were packed and sent (3 d nonrefrigerated transit) to North Carolina State University for sensory analysis of the whole fruit. Upon receipt, apples were held in refrigerated storage until use $(<7 \mathrm{~d})$.

Starch index was determined visually using a rating scale of 1 to 6 (Washington Apple Maturity Program, 1993). Firmness was determined at two locations per fruit with the texture analyzer (Ta-XT2; Texture Technologies, Scarsdale, N.Y.) equipped with a 11.1-mm probe. SSC and TA were determined from an aliquot of expressed juice from a crosssectional slice from each of the same 10 fruit. SSC was determined with a model 10450 refractometer (American Optical, Buffalo, N.Y.) equipped with a sucrose scale and calibrated with distilled $\mathrm{H}_{2} \mathrm{O}$ at $20^{\circ} \mathrm{C}$ TA was measured with a titrator (model TTT85; Radiometer, Copenhagen, Denmark). Acids were titrated to $\mathrm{pH} 8.2$ with $0.1 \mathrm{~N} \mathrm{NaOH}$ and expressed as percent malic acid. Peel and flesh color was determined with the ColorFlex model 45/0 (Hunter Labs, Reston, Va.) using the Hunter $L^{*}, a^{*}, b^{*}$ system and calculated hue angle $\left(h^{\circ}\right)$ values (Hunter and Harold, 1987). IEC was determined on five fruit for each replication, treatment, and storage period using a GC-FID (model 5880A; Hewlett Packard, Avondale, Pa.) equipped with a Porapak Q column. Fruit disorders were visually assessed by laboratory personnel and expressed as the percentage of each fruit sample showing the disorder. All data were analyzed using the General Linear Models (GLM) procedure of the Statistical Analysis System (SAS) program package (SAS Institute, Cary, N.C.). Where appropriate, means were separated by Tukey's test $(P \leq 0.05)$.

Juice preparation. For each treatment and replication, ten randomly selected apples were washed, surface dried, sliced and juiced using a juicer (model 4000; Omega Products, Inc., Harrisburg, Pa.) at ambient temperature. Juice was centrifuged in an IEC (Centra-7; International Equipment, Co., Needham Heights, Mass.) at $523 \mathrm{rad} / \mathrm{s}$ and then filtered through an odor-free coffee filter to remove all insoluble solids. The juice from each group within a treatment was combined and stored at $5.6{ }^{\circ} \mathrm{C}$ for immediate flavor panel evaluation.

Sensory analysis: Juice. Sensory testing was conducted on apple juice samples in a laboratory environment by a panel of 25 judges that had previously been trained in apple juice flavor attributes (Tree Top, Inc., Selah, Wash.). Each panelist received two samples that were color coded to indicate a control and a treatment sample. Panelists were not aware of the relationship of color coding to treatment and were instructed before the evaluation on the proper method for filling out the ballot describing their choices. Each evaluation session was limited to two groups of two samples (four juice samples in total).

The ballot consisted of three parts. Each panelist was asked to make a preference choice between the two samples after tasting the samples in the prescribed order. In addition, each panelist was asked to rate the intensity of the apple flavor for each sample using a 9-point scale, where $1=$ indicated that the apple flavor was too weak, $5=$ that the apple flavor was just right, and $9=$ that the flavor was too strong. Finally, each panelist was asked to rate their overall degree of liking of each juice sample using a 9-point scale, where $1=$ dislike extremely, $5=$ neither like nor dislike, and $9=$ like extremely.

Sensory analysis of whole apples. Consumers $(N \geq 100)$ were recruited at the North Carolina State University (NCSU) Sensory Service Center, Raleigh, N.C., before each taste test. Consumers evaluated freshly cut and cored apple slices for overall liking, flavor and texture acceptability using a 9-point hedonic scale anchored on the left with "dislike extremely" and on the right with "like extremely" (Meilgaard et al., 1999). Apples were presented in a randomized, balanced order of presentation on paper plates with a random three-digit code designating each treatment on each plate. Before testing, each consumer panelist filled out an informed consent form for NCSU Human Subjects Approval and a brief questionnaire on apple consumption habits.

Consumer taste-panel demographics were similar for the various harvests each year. Consumers were fairly evenly split between genders ( $58 \%$ female, $42 \%$ male); $55 \%$ were between 19 and 29 years old and $45 \%$ were between 30 and 55 years old. All consumer participants indicated a liking for apples, but frequency of apple consumption varied widely. Forty percent consumed apples seasonally or a least once per month, while $35 \%$ consumed apples a few times per week. Consumers were also asked to list the apple cultivars they consumed most often. 'Delicious' (62\%), 'Fuji' (47\%), 'Granny Smith' (58\%), 'Golden Delicious' (51\%), 'Gala' (42\%), and 'McIntosh' (23\%) were the most commonly cited cultivars. Of consumer panelists, $85 \%$ indicated that flavor was a critical factor in apple choice and purchase; $72 \%$ indicated texture and $51 \%$ indicated that color was a critical factor in apple choice and purchase.

\section{Results and Discussion}

AVG retarded flesh firmness and starch loss independent of harvest date but did not affect SSC, TA, or SSC to TA ratio (Table 1). Delaying harvest by 2 weeks resulted in reduced flesh firmness and TA and increased starch hydrolysis. ETH treatments had no influence on fruit firmness but increased SSC to TA ratio (300 $\mathrm{mg} \cdot \mathrm{L}^{-1}$ treatments only) and starch hydrolysis while having no effect on TA levels. A 2-week harvest delay again resulted in reduced firmness and increased starch hy- 
drolysis but had no effect on SSC, TA or SSC to TA ratio. Fruit weight was not affected by bioregulator treatments but was greater on the second harvest date (data not shown). The effects of delaying harvest produced similar responses in fruit quality parameters in both Trials 1 and 2 .

AVG treatment resulted in reduced peel red color development that would not be visible to the average consumer due to the significant but small corresponding change in hue value (Table 2 ). A change in hue value of one or more unit is required to visually identify color differences (Hunter and Harold, 1987). AVG treatment reduced color development in other less highly colored apple cultivars (Greene, 2002; Wang and Dilley, 2001). Delaying harvest by 2 weeks in this study resulted in small changes in L values but no observable change in peel hue value. In contrast, AVG treatment produced apple flesh color that was more green (higher hue value) than nontreated apples. Greener flesh color could be related to slower maturity, which was indicated by the reduction in starch hydrolysis (Table 1). ETH did not influence the peel color of apples regardless of the amount of ETH applied or time of application. This result did not agree with the increased red color observations of Larrigaudiere et al. (1996) and Stover et al. (2003), but those studies were not conducted with the Scarletspur strain of 'Delicious', which is characterized by intense, early red color development in the peel. However, ETH produced a darker flesh color (lower L values), with less green and more yellow. The lower hue values associated with ETH application indicated a flesh color typical of more mature fruit. These changes in flesh color were very evident re- gardless of the amount of ETH applied or time of application. The higher ETH concentration tended to have more influence on flesh color than the lower $\left(150 \mathrm{mg} \cdot \mathrm{L}^{-1}\right)$, particularly when applied at $1 \mathrm{WBH}$, which allowed less time for the ETH effect to be developed.

After both RA (60 d) and CA (150 d) storage, AVG-treated fruit were firmer than nontreated apples, regardless of harvest date (Table 2). After both $60 \mathrm{~d}$ RA and $150 \mathrm{~d}$ CA storage, all fruit met or exceeded the minimum Washington State grade standard for firmness of 54 N (Washington Agriculture Code, 1990). However,AVG-treated fruit were substantially firmer than untreated fruit, indicating that AVG treatment resulted in better tissue texture conservation under RA and CA storage conditions.

After 60 d of RAstorage, all fruit, regardless

Table 1. Effects of aminoethoxyvinylglycine (AVG) or ethephon (ETH) applied preharvest on objective quality attributes of 'Delicious' (Scarletspur strain) apples at harvest (Trials 1 and 2, 2000).

\begin{tabular}{|c|c|c|c|c|c|}
\hline Parameter & $\begin{array}{c}\text { Firmness } \\
(\mathrm{N})\end{array}$ & $\begin{array}{l}\text { SSC } \\
(\%)\end{array}$ & $\begin{array}{c}\mathrm{TA} \\
(\% \text { malic) }\end{array}$ & $\begin{array}{c}\mathrm{SSC} \text { to } \\
\mathrm{TA} \\
\text { ratio }\end{array}$ & $\begin{array}{l}\text { Starch } \\
(1 \text { to } 6)\end{array}$ \\
\hline \multicolumn{6}{|l|}{$\overline{\text { Bioregulator }}$} \\
\hline Control & $72.2 b^{2}$ & $11.2 \mathrm{a}$ & $0.26 \mathrm{a}$ & $44.2 \mathrm{a}$ & $1.8 \mathrm{a}$ \\
\hline \multicolumn{6}{|l|}{ Harvest } \\
\hline 20 Sept. & $75.7 \mathrm{a}$ & $11.2 \mathrm{a}$ & $0.26 \mathrm{a}$ & $43.9 \mathrm{a}$ & $1.5 \mathrm{~b}$ \\
\hline 4 Oct. & $73.0 \mathrm{~b}$ & $11.2 \mathrm{a}$ & $0.25 \mathrm{a}$ & $45.9 \mathrm{a}$ & $2.0 \mathrm{a}$ \\
\hline Control & $70.4 \mathrm{a}$ & $11.5 \mathrm{~b}$ & $0.24 \mathrm{a}$ & $48.9 \mathrm{~b}$ & $2.6 \mathrm{c}$ \\
\hline ETH $150 \mathrm{mg} \cdot \mathrm{L}^{-1}(2 \mathrm{WBH})^{\mathrm{x}}$ & $68.9 \mathrm{a}$ & $12.3 \mathrm{a}$ & $0.24 \mathrm{a}$ & $52.0 \mathrm{ab}$ & $3.3 \mathrm{ab}$ \\
\hline ETH $300 \mathrm{mg} \cdot \mathrm{L}^{-1}(2 \mathrm{WBH})^{\mathrm{x}}$ & $68.2 \mathrm{a}$ & $12.6 \mathrm{a}$ & $0.24 \mathrm{a}$ & $53.7 \mathrm{a}$ & $3.4 \mathrm{a}$ \\
\hline ETH $150 \mathrm{mg} \cdot \mathrm{L}^{-1}(1 \mathrm{WBH})^{\mathrm{w}}$ & $69.8 \mathrm{a}$ & $12.2 \mathrm{a}$ & $0.24 \mathrm{a}$ & $51.9 \mathrm{ab}$ & $3.1 \mathrm{~b}$ \\
\hline ETH $300 \mathrm{mg} \cdot \mathrm{L}^{-1}(1 \mathrm{WBH})^{\mathrm{w}}$ & $68.3 \mathrm{a}$ & $12.3 \mathrm{a}$ & $0.23 \mathrm{a}$ & $52.6 \mathrm{a}$ & $3.2 \mathrm{ab}$ \\
\hline \multicolumn{6}{|l|}{ Harvest } \\
\hline 18 Sept. & $71.5 \mathrm{a}$ & $12.1 \mathrm{a}$ & $0.24 \mathrm{a}$ & $51.3 \mathrm{a}$ & $2.5 \mathrm{~b}$ \\
\hline
\end{tabular}

${ }^{2}$ Means in a column within bioregulator or harvest not followed by a common letter are significantly different $(P \leq 0.05)$.

${ }^{\mathrm{y}} \mathrm{AVG}$ applied 4 weeks before first harvest.

${ }^{\times}$ETH applied 2 weeks before first harvest.

"ETH applied 1 week before first harvest.

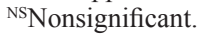

Table 2. Effects of aminoethoxyvinylglycine (AVG) or ethephon (ETH) applied preharvest on objective color attributes of 'Delicious' (Scarletspur strain) apples at harvest and firmness values after regular atmosphere (RA) and controlled atmosphere storage (Trials 1 and 2, 2000).

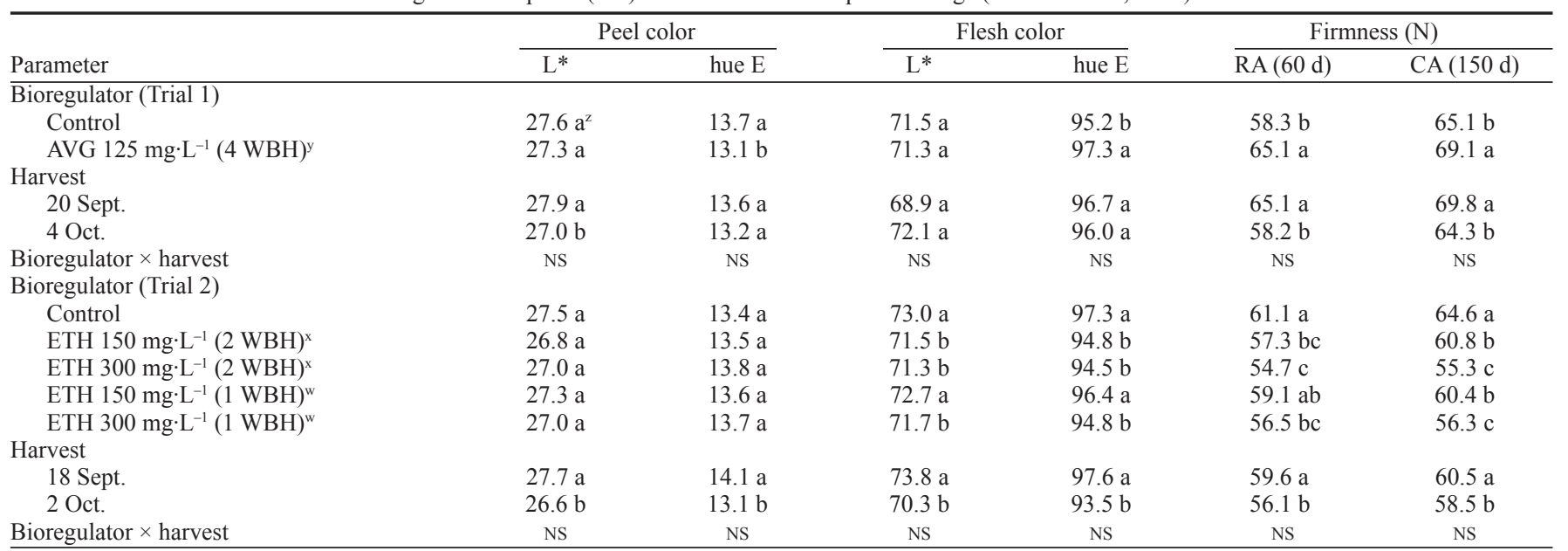

${ }^{2}$ Means in a column within bioregulator or harvest not followed by a common letter are significantly different $(P \leq 0.05)$.

${ }^{y} \mathrm{AVG}$ applied 4 weeks before first harvest.

${ }^{x}$ ETH applied 2 weeks before first harvest.

"ETH applied 1 week before first harvest.

NSNonsignificant. 
Table 3. Effects of aminoethoxyvinylglycine (AVG) and ethephon (ETH) applied alone or sequentially, preharvest on sensory evaluation of 'Delicious' (Scarletspur strain) apple juice from fruit at harvest (Trial 2, 2000; Trial 3, 2001; Trial 4, 2002).

\begin{tabular}{|c|c|c|c|c|c|c|c|}
\hline \multirow[b]{2}{*}{ Treatment/year } & \multirow[b]{2}{*}{$\mathrm{N}$} & \multicolumn{3}{|c|}{ Harvest I } & \multicolumn{3}{|c|}{ Harvest II } \\
\hline & & Preference $^{z}$ & Intensity & Liking & Preference & Intensity & Liking \\
\hline Control & 100 & & $3.9 \mathrm{~b}^{\mathrm{y}}$ & $6.0 \mathrm{~b}$ & & $4.4 \mathrm{~b}$ & $7.3 \mathrm{ab}$ \\
\hline ETH $150 \mathrm{mg} \cdot \mathrm{L}^{-1}(1 \mathrm{WBH})^{\mathrm{v}}$ & 25 & $\mathrm{~T}$ & $5.2 \mathrm{a}$ & $7.5 \mathrm{a}$ & $\mathrm{T}$ & $4.6 \mathrm{ab}$ & $6.8 \mathrm{~b}$ \\
\hline ETH $300 \mathrm{mg} \cdot \mathrm{L}^{-1}(1 \mathrm{WBH})^{\mathrm{v}}$ & 25 & $\mathrm{~T}$ & $5.1 \mathrm{a}$ & $7.4 \mathrm{a}$ & $\mathrm{N}$ & $4.6 \mathrm{ab}$ & $6.9 \mathrm{~b}$ \\
\hline \multicolumn{8}{|l|}{ Trial 3, 2001} \\
\hline $\mathrm{AVG}+\mathrm{ETH} 150 \mathrm{mg} \cdot \mathrm{L}^{-1}(2 \mathrm{WBH})^{\mathrm{w}}$ & 25 & $\mathrm{~T}$ & $4.9 \mathrm{a}$ & $7.1 \mathrm{ab}$ & $\mathrm{T}$ & $5.2 \mathrm{a}$ & $7.4 \mathrm{a}$ \\
\hline $\mathrm{AVG}+\mathrm{ETH} 300 \mathrm{mg} \cdot \mathrm{L}^{-1}(2 \mathrm{WBH})^{\mathrm{w}}$ & 25 & $\mathrm{~T}$ & $5.1 \mathrm{a}$ & $7.4 \mathrm{a}$ & $\mathrm{T}$ & $5.2 \mathrm{a}$ & $7.4 \mathrm{a}$ \\
\hline $\mathrm{AVG}+\mathrm{ETH} 150 \mathrm{mg} \cdot \mathrm{L}^{-1}(1 \mathrm{WBH})^{\mathrm{v}}$ & 25 & $\mathrm{~T}$ & $4.8 \mathrm{a}$ & $7.4 \mathrm{a}$ & $\mathrm{T}$ & $5.3 \mathrm{a}$ & $7.3 \mathrm{a}$ \\
\hline $\mathrm{AVG}+\mathrm{ETH} 300 \mathrm{mg} \cdot \mathrm{L}^{-1}(1 \mathrm{WBH})^{\mathrm{v}}$ & 25 & $\mathrm{~N}$ & $4.9 \mathrm{a}$ & $7.0 \mathrm{~b}$ & $\mathrm{~N}$ & $4.4 \mathrm{c}$ & $6.5 \mathrm{a}$ \\
\hline \multicolumn{8}{|l|}{ Trial 4, 2002} \\
\hline Control & 250 & & $4.0 \mathrm{~b}$ & $6.4 \mathrm{a}$ & & $4.8 \mathrm{ab}$ & $7.3 \mathrm{a}$ \\
\hline AVG $125 \mathrm{mg} \cdot \mathrm{L}^{-1}(4 \mathrm{WBH})^{\mathrm{x}}$ & 50 & $\mathrm{~T}$ & $4.6 \mathrm{a}$ & $6.9 \mathrm{a}$ & $\mathrm{N}$ & $5.0 \mathrm{a}$ & $7.3 \mathrm{a}$ \\
\hline
\end{tabular}

${ }^{2}$ Significantly preferred $(P \leq 0.05)$ : $\mathrm{C}=$ control, $\mathrm{T}=$ treatment, $\mathrm{N}=$ neither control or treatment preferred.

${ }^{y}$ Means in a column not followed by a common letter are significantly different $(P \leq 0.05)$.

${ }^{x}$ AVG applied 4 weeks before first harvest.

${ }^{w}$ ETH applied 2 weeks before first harvest either with or without AVG applied 4 weeks before first harvest.

${ }^{\vee}$ ETH applied 1 week before first harvest either with or without AVG applied 4 weeks before first harvest.

"ETH applied at either 2 weeks or 2 weeks and 1 week before first harvest either with or without AVG applied 4 weeks before first harvest.

Table 4. Effects of aminoethoxyvinylglycine (AVG) applied alone or sequentially with ethephon (ETH) on consumer sensory evaluation of 'Delicious' (Scarletspur strain) apples at harvest (Trial 3, 2001).

\begin{tabular}{|c|c|c|c|c|c|c|c|}
\hline & \multicolumn{4}{|c|}{ Objective quality } & \multicolumn{3}{|c|}{ Sensory evaluation (whole apples) } \\
\hline & $\begin{array}{c}\text { Firmness } \\
(\mathrm{N})\end{array}$ & $\begin{array}{l}\text { SSC } \\
(\%)\end{array}$ & $\begin{array}{c}\text { TA } \\
(\% \text { malic })\end{array}$ & $\begin{array}{l}\text { SSC to } \\
\text { TA ratio }\end{array}$ & Overall & Flavor & Texture \\
\hline \multicolumn{8}{|l|}{ Bioregulator } \\
\hline AVG $125 \mathrm{mg} \cdot \mathrm{L}^{-1}(4 \mathrm{WBH})^{\mathrm{x}}$ & $73.7 \mathrm{~b}$ & $11.3 \mathrm{~b}$ & $0.28 \mathrm{a}$ & $42.1 \mathrm{c}$ & $6.1 \mathrm{c}$ & $5.8 \mathrm{c}$ & $6.5 \mathrm{~b}$ \\
\hline $\mathrm{AVG}+\mathrm{ETH} 150 \mathrm{mg} \cdot \mathrm{L}^{-1}(2 \mathrm{WBH})^{\mathrm{w}}$ & $76.5 \mathrm{ab}$ & $11.7 \mathrm{a}$ & $0.28 \mathrm{a}$ & $43.4 \mathrm{bc}$ & $6.6 \mathrm{ab}$ & $6.5 \mathrm{ab}$ & $6.9 \mathrm{ab}$ \\
\hline $\mathrm{AVG}+\mathrm{ETH} 300 \mathrm{mg} \cdot \mathrm{L}^{-1}(2 \mathrm{WBH})^{\mathrm{w}}$ & $74.4 \mathrm{~b}$ & $12.0 \mathrm{a}$ & $0.27 \mathrm{a}$ & $45.5 \mathrm{ab}$ & $6.7 \mathrm{a}$ & $6.7 \mathrm{a}$ & $7.0 \mathrm{a}$ \\
\hline $\mathrm{AVG}+\mathrm{ETH} 150 \mathrm{mg} \cdot \mathrm{L}^{-1}(1 \mathrm{WBH})^{\mathrm{v}}$ & $77.0 \mathrm{ab}$ & $11.7 \mathrm{a}$ & $0.27 \mathrm{a}$ & $44.4 \mathrm{ab}$ & $6.5 \mathrm{ab}$ & $6.4 \mathrm{~b}$ & $7.0 \mathrm{a}$ \\
\hline I & $80.0 \mathrm{a}$ & $10.5 \mathrm{~b}$ & $0.31 \mathrm{a}$ & $34.3 \mathrm{~b}$ & $6.3 \mathrm{~b}$ & $6.2 \mathrm{~b}$ & $6.7 \mathrm{~b}$ \\
\hline II & $71.3 \mathrm{~b}$ & $12.8 \mathrm{a}$ & $0.24 \mathrm{~b}$ & $53.6 \mathrm{a}$ & $6.6 \mathrm{a}$ & $6.5 \mathrm{a}$ & $7.0 \mathrm{a}$ \\
\hline Bioregulator $\times$ harvest & NS & NS & NS & NS & NS & NS & NS \\
\hline
\end{tabular}

${ }^{\mathrm{z}} \mathrm{N}=240$.

${ }^{y}$ Means in a column within bioregulator or harvest not followed by a common letter are significantly different $(P \leq 0.05)$.

${ }^{\mathrm{x}} \mathrm{AVG}$ applied 4 weeks before first harvest.

${ }^{\text {w}} \mathrm{AVG}$ applied at $125 \mathrm{mg} \cdot \mathrm{L}^{-1} 4$ weeks before first harvest followed by ETH at $150 \mathrm{or} 300 \mathrm{mg} \cdot \mathrm{L}^{-1}$ at 2 weeks before first harvest.

${ }^{\mathrm{v}} \mathrm{AVG}$ applied at $125 \mathrm{mg} \cdot \mathrm{L}^{-1} 4$ weeks before first harvest followed by ETH at 150 or $300 \mathrm{mg} \cdot \mathrm{L}^{-1}$ at 1 week before first harvest.

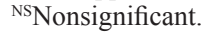

Table 5. Effects of aminoethoxyvinylglycine (AVG) and ethephon (ETH) applied alone or sequentially on objective and consumer sensory evaluation of 'Delicious' (Scarletspur strain) apples at harvest (Trial 4, 2002).

\begin{tabular}{|c|c|c|c|c|c|c|c|}
\hline & \multicolumn{4}{|c|}{ Objective quality } & \multicolumn{3}{|c|}{ Sensory evaluation (whole apples) } \\
\hline & $\begin{array}{l}\text { Firmness } \\
(\mathrm{N})\end{array}$ & $\begin{array}{l}\text { SSC } \\
(\%)\end{array}$ & $\begin{array}{c}\text { TA } \\
(\% \text { malic })\end{array}$ & $\begin{array}{l}\text { SSC to } \\
\text { TA ratio }\end{array}$ & Overall & Flavor & Texture \\
\hline \multicolumn{8}{|l|}{ Bioregulator } \\
\hline AVG $125 \mathrm{mg} \cdot \mathrm{L}^{-1}(4 \mathrm{WBH})^{\mathrm{x}}$ & $80.2 \mathrm{a}$ & $11.4 \mathrm{c}$ & $0.24 \mathrm{a}$ & $47.0 \mathrm{c}$ & $6.0 \mathrm{c}$ & $5.9 \mathrm{c}$ & $6.4 \mathrm{bc}$ \\
\hline ETH $75 \mathrm{mg} \cdot \mathrm{L}^{-1}(2 \text { and } 1 \mathrm{WBH})^{\mathrm{w}}$ & $77.3 \mathrm{~b}$ & $12.1 \mathrm{a}$ & $0.24 \mathrm{a}$ & $51.3 \mathrm{ab}$ & $6.3 \mathrm{abc}$ & $6.3 \mathrm{ab}$ & $6.3 \mathrm{c}$ \\
\hline ETH $150 \mathrm{mg} \cdot \mathrm{L}^{-1}(2 \mathrm{WBH})^{\mathrm{w}}$ & $78.4 \mathrm{ab}$ & $12.2 \mathrm{a}$ & $0.24 \mathrm{a}$ & $50.5 \mathrm{ab}$ & $6.5 \mathrm{a}$ & $6.5 \mathrm{a}$ & $6.5 \mathrm{bc}$ \\
\hline $\mathrm{AVG}+\mathrm{ETH} 75 \mathrm{mg} \cdot \mathrm{L}^{-1}(2 \text { and } 1 \mathrm{WBH})^{\mathrm{v}}$ & $80.1 \mathrm{a}$ & $12.4 \mathrm{a}$ & $0.23 \mathrm{a}$ & $52.9 \mathrm{a}$ & $6.4 \mathrm{ab}$ & $6.3 \mathrm{ab}$ & $6.7 \mathrm{ab}$ \\
\hline I & $81.0 \mathrm{a}$ & $11.6 \mathrm{~b}$ & $0.24 \mathrm{a}$ & $49.0 \mathrm{~b}$ & $6.2 \mathrm{~b}$ & $6.1 \mathrm{~b}$ & $6.5 \mathrm{a}$ \\
\hline II & $77.2 \mathrm{~b}$ & $12.4 \mathrm{a}$ & $0.24 \mathrm{a}$ & $51.1 \mathrm{a}$ & $6.5 \mathrm{a}$ & $6.5 \mathrm{a}$ & $6.6 \mathrm{a}$ \\
\hline Bioregulator $\times$ harvest & NS & NS & NS & NS & NS & NS & NS \\
\hline
\end{tabular}

${ }^{\mathrm{z}} \mathrm{N}=210$.

y Means in a column within bioregulator or harvest not followed by a common letter are significantly different $(P \leq 0.05)$.

${ }^{x}$ AVG applied 4 weeks before first harvest.

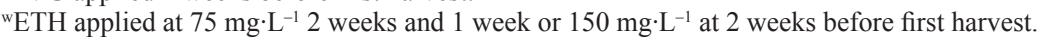

${ }^{v}$ AVG applied at $125 \mathrm{mg} \cdot \mathrm{L}^{-1} 4$ weeks before first harvest followed by ETH at $75 \mathrm{mg} \cdot \mathrm{L}^{-1} 2$ weeks and 1 week or $150 \mathrm{mg} \cdot \mathrm{L}^{-1}$ at 2 weeks before first harvest.

${ }^{\text {NSNonsignificant. }}$ 
of concentration, time of application, or harvest date, met the minimum Washington State grade standard for firmness, although the ETH 300 (2 WBH) treatment just barely met the standard (Table 2). After $150 \mathrm{~d}$ of CA storage, control fruit were firmer than any ETH treatment, and again all treatments met the minimum firmness standard, with the high ETH concentration fruit just exceeding that value. Fruit from the later harvest date were less firm after both 60 and $150 \mathrm{~d}$ of storage, but all fruit met the minimum firmness standard.

Applications of ETH alone to apples at 150 or $300 \mathrm{mg} \cdot \mathrm{L}^{-1}$ at 1 or $2 \mathrm{WBH}$ increased the preference, intensity and liking sensory scores of apple juice on both harvest dates over juice from untreated fruit (Table 3, Trial 2, 2000). Apple juice flavor intensity scores for the ETH treatments groups were closer to the 5.0 score of "just right" while the control group flavor intensity score was more toward "weak". At the second harvest the improvement in quality perception from preharvest ETH applications when compared to controls was not as conspicuous. Apple juice flavor intensity from the ETH 2 WBH group was near the 5.0 scale of "just right" while the juice from the ETH 1
WBH group and the control group were toward the "weak" intensity score. Liking scores followed a similar pattern in which the $2 \mathrm{WBH}$ group apple juice exhibited higher scores than the $1 \mathrm{WBH}$ group. Because of better flavor intensity and liking scores, apple juice from all the second harvest treatment groups except the $300 \mathrm{mg} \cdot \mathrm{L}^{-1} \mathrm{ETH}(1 \mathrm{WBH})$ were preferred over the juice from the control group. At the second harvest (II), control fruit had matured enough that only apples treated with 300 $\mathrm{mg} \cdot \mathrm{L}^{-1} \mathrm{ETH}$ at $2 \mathrm{WBH}$ produced juice with preference, intensity and liking scores superior to nontreated fruit.

Apple juice samples from apples treated with AVG alone were similar in preference, intensity and liking to juice from control fruit at the first harvest (Table 3, Trial 3, 2001). Juice from apples treated with ETH in addition to $\mathrm{AVG}$ was preferred to juice made from control fruit, except when $300 \mathrm{mg} \cdot \mathrm{L}^{-1} \mathrm{ETH}$ was applied $1 \mathrm{WBH}$; in this instance there was no difference in preference. Apple juice flavor intensity scores were similar among bioregulator treatments and control fruit. Apple juice from apples treated with a combination of AVG and ETH ( 150 or $300 \mathrm{mg} \cdot \mathrm{L}^{-1}, 2 \mathrm{WBH}$ ) was scored higher for liking when compared to juice from control fruit. All other treatments received similar scores to control fruit juice for liking.

At the second harvest, juice from control fruit was preferred to juice made from apples treated with AVG alone (Table 3, Trial 3, 2001). When ETH was applied in conjunction with AVG, preference scores for juice were superior to juice from control fruit, except again in the instance where ETH was applied at 300 $\mathrm{mg} \cdot \mathrm{L}^{-1} 1 \mathrm{WBH}$. By the second harvest, control fruit had matured enough that juice scores for apple flavor intensity were similar to all AVG + ETH treatments, although AVG alone had a lower intensity score than three of four AVG + ETH treatments. When AVG and ETH were used sequentially, juice liking scores from some of the treatments were preferred at the first harvest, but no differences in juice liking were detected at the second harvest.

In the final year of the study, apple juice from fruit treated with AVG was preferred when compared to juice from control fruit, but only at the first harvest (Table 3, Trial 4, 2002). At the second harvest no preference was indicated between juice from AVG treated or control

Table 6. Effects of aminoethoxyvinylglycine (AVG) applied alone or sequentially with ethephon (ETH) and harvest date on starch level at harvest and flesh firmness of 'Delicious' (Scarletspur strain) apples after regular (RA) or controlled atmosphere (CA) storage (Trial 3, 2001).

\begin{tabular}{|c|c|c|c|c|c|}
\hline \multirow[b]{2}{*}{ Bioregulator } & \multirow[b]{2}{*}{ Harvest } & \multirow{2}{*}{$\begin{array}{c}\text { Starch (1-6) } \\
\text { at Harvest }\end{array}$} & \multicolumn{3}{|c|}{ Firmness $(\mathrm{N})$} \\
\hline & & & RA $(60 d)$ & $\mathrm{CA}(120 \mathrm{~d})$ & CA $(180 \mathrm{~d})$ \\
\hline Control & II & $2.7 \mathrm{a}$ & $54.5 \mathrm{~h}$ & $53.9 \mathrm{~g}$ & $48.4 \mathrm{de}$ \\
\hline \multirow[t]{2}{*}{$\mathrm{AVG}+\mathrm{ETH} 150 \mathrm{mg} \cdot \mathrm{L}^{-1}(2 \mathrm{WBH})^{\mathrm{x}}$} & I & $1.6 \mathrm{~cd}$ & $66.4 \mathrm{c}$ & $67.0 \mathrm{ab}$ & $66.8 \mathrm{a}$ \\
\hline & II & $2.6 \mathrm{ab}$ & $58.7 \mathrm{ef}$ & $59.6 \mathrm{ef}$ & $53.3 \mathrm{~cd}$ \\
\hline $\mathrm{AVG}+\mathrm{ETH} 300 \mathrm{mg} \cdot \mathrm{L}^{-1}(2 \mathrm{WBH})^{\mathrm{x}}$ & I & $1.8 \mathrm{c}$ & $66.6 \mathrm{c}$ & $66.1 \mathrm{bc}$ & $65.8 \mathrm{a}$ \\
\hline & II & $2.6 \mathrm{ab}$ & $59.4 \mathrm{ef}$ & $59.8 \mathrm{ef}$ & $54.8 \mathrm{bc}$ \\
\hline \multirow[t]{2}{*}{$\mathrm{AVG}+\mathrm{ETH} 300 \mathrm{mg} \cdot \mathrm{L}^{-1}(1 \mathrm{WBH})^{\mathrm{w}}$} & I & $1.6 \mathrm{~cd}$ & $67.0 \mathrm{bc}$ & $67.5 \mathrm{ab}$ & $66.6 \mathrm{a}$ \\
\hline & II & $2.8 \mathrm{a}$ & $58.0 \mathrm{fg}$ & $58.0 \mathrm{f}$ & $52.2 \mathrm{cde}$ \\
\hline Bioregulator $\times$ harvest & * & $*$ & * & $*$ & $*$ \\
\hline
\end{tabular}

${ }^{\mathrm{z}}$ Means in a column not followed by a common letter are significantly different $(P \leq 0.05)$.

${ }^{\mathrm{y}} \mathrm{AVG}$ applied 4 weeks before first harvest.

${ }^{x}$ AVG applied at $125 \mathrm{mg} \cdot \mathrm{L}^{-1} 4$ weeks before first harvest followed by ETH at $150 \mathrm{or} 300 \mathrm{mg} \cdot \mathrm{L}^{-1} 2$ weeks before first harvest.

wAVG applied at $125 \mathrm{mg} \cdot \mathrm{L}^{-1} 4$ weeks before first harvest followed by ETH at $150 \mathrm{or} 300 \mathrm{mg} \cdot \mathrm{L}^{-1} 1$ week before first harvest.

*Significant at $P \leq 0.05$.

Table 7. Effects of aminoethoxyvinylglycine (AVG) applied alone or sequentially with ethephon (ETH) and harvest date on Hunter peel color parameters of 'Delicious' (Scarletspur strain) apples at harvest and after regular (RA) or controlled atmosphere (CA) storage (Trial 3, 2001).

\begin{tabular}{|c|c|c|c|c|c|c|c|}
\hline \multirow[b]{2}{*}{ Bioregulator } & \multirow[b]{2}{*}{ Harvest } & \multicolumn{2}{|c|}{ RA (60 d) } & \multicolumn{2}{|c|}{ CA $(120 \mathrm{~d})$} & \multicolumn{2}{|c|}{ CA $(180 \mathrm{~d})$} \\
\hline & & $\mathrm{L}^{*}$ & hue $(\mathrm{E})$ & $\mathrm{L}^{*}$ & hue $(\mathrm{E})$ & $\mathrm{L}^{*}$ & hue $(\mathrm{E})$ \\
\hline \multirow[t]{2}{*}{ Control } & I & $32.4 \mathrm{a}$ & $18.9 \mathrm{a}$ & $31.8 \mathrm{a}$ & $18.7 \mathrm{a}$ & $31.6 \mathrm{a}$ & $20.2 \mathrm{a}$ \\
\hline & II & $26.7 \mathrm{de}$ & $15.6 \mathrm{~cd}$ & $26.4 \mathrm{de}$ & 15.9 cde & $25.7 \mathrm{c}$ & $16.1 \mathrm{cdef}$ \\
\hline \multirow[t]{2}{*}{ AVG $125 \mathrm{mg} \cdot \mathrm{L}^{-1}(4 \mathrm{WBH})^{\mathrm{y}}$} & $\mathrm{I}$ & $30.9 \mathrm{~b}$ & $18.3 \mathrm{ab}$ & $31.0 \mathrm{ab}$ & $18.5 \mathrm{ab}$ & $30.7 \mathrm{ab}$ & $18.2 \mathrm{~b}$ \\
\hline & II & $27.1 \mathrm{~d}$ & $15.2 \mathrm{~d}$ & $27.1 \mathrm{~d}$ & $15.1 \mathrm{e}$ & $26.4 \mathrm{c}$ & $15.6 \mathrm{efg}$ \\
\hline \multirow[t]{2}{*}{$\mathrm{AVG}+\mathrm{ETH} 150 \mathrm{mg} \cdot \mathrm{L}^{-1}(2 \mathrm{WBH})^{\mathrm{x}}$} & $\mathrm{I}$ & $29.3 \mathrm{c}$ & $16.9 \mathrm{bc}$ & $29.8 \mathrm{c}$ & $17.0 \mathrm{bcd}$ & $29.9 \mathrm{~b}$ & 17.5 bcde \\
\hline & II & $25.8 \mathrm{e}$ & $14.6 \mathrm{~d}$ & $26.2 \mathrm{de}$ & $15.3 \mathrm{e}$ & $25.1 \mathrm{c}$ & $15.5 \mathrm{fg}$ \\
\hline \multirow[t]{2}{*}{$\mathrm{AVG}+\mathrm{ETH} 300 \mathrm{mg} \cdot \mathrm{L}^{-1}(2 \mathrm{WBH})^{\mathrm{x}}$} & $\mathrm{I}$ & $30.0 \mathrm{bc}$ & $17.1 \mathrm{~b}$ & $29.6 \mathrm{c}$ & $17.3 \mathrm{abc}$ & $30.1 \mathrm{~b}$ & $17.7 \mathrm{bc}$ \\
\hline & II & $26.2 \mathrm{de}$ & $15.6 \mathrm{~cd}$ & $25.8 \mathrm{e}$ & $15.7 \mathrm{de}$ & $22.2 \mathrm{~d}$ & $13.8 \mathrm{~g}$ \\
\hline \multirow[t]{2}{*}{$\mathrm{AVG}+\mathrm{ETH} 150 \mathrm{mg} \cdot \mathrm{L}^{-1}(1 \mathrm{WBH})^{\mathrm{w}}$} & $\mathrm{I}$ & $29.9 \mathrm{bc}$ & $17.1 \mathrm{~b}$ & $30.1 \mathrm{bc}$ & $17.8 \mathrm{ab}$ & $30.2 \mathrm{~b}$ & $17.6 \mathrm{bcd}$ \\
\hline & II & $26.2 \mathrm{de}$ & $15.0 \mathrm{~d}$ & $26.2 \mathrm{de}$ & $15.3 \mathrm{e}$ & $25.4 \mathrm{c}$ & $15.6 \mathrm{efg}$ \\
\hline \multirow[t]{2}{*}{$\mathrm{AVG}+\mathrm{ETH} 300 \mathrm{mg} \cdot \mathrm{L}^{-1}(1 \mathrm{WBH})^{\mathrm{w}}$} & $\mathrm{I}$ & $30.7 \mathrm{~b}$ & $17.7 \mathrm{ab}$ & $30.1 \mathrm{bc}$ & $17.9 \mathrm{ab}$ & $30.6 \mathrm{ab}$ & $17.9 \mathrm{bc}$ \\
\hline & II & 26.0 de & $15.1 \mathrm{~d}$ & $25.5 \mathrm{e}$ & $15.0 \mathrm{c}$ & $25.0 \mathrm{c}$ & 15.7 defg \\
\hline Bioregulator $\times$ harvest & & $*$ & $*$ & $*$ & $*$ & * & $*$ \\
\hline
\end{tabular}

${ }^{\mathrm{z}}$ Means in a column not followed by a common letter are significantly different $(P \leq 0.05)$.

y AVG applied 4 weeks before first harvest.

${ }^{\mathrm{x}} \mathrm{AVG}$ applied at $125 \mathrm{mg} \cdot \mathrm{L}^{-1} 4$ weeks before first harvest followed by ETH at 150 or $300 \mathrm{mg} \cdot \mathrm{L}^{-1} 2$ weeks before first harvest.

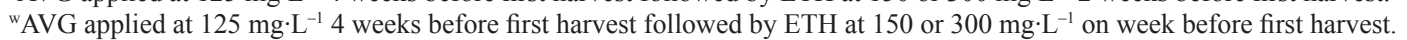

"Significant at $P \leq 0.05$. 
apples. At the first harvest, juice from treated ETH fruit was preferred, except when ETH was applied at $150 \mathrm{mg} \cdot \mathrm{L}^{-1}(2 \mathrm{WBH})$. In this instance apple intensity was also reduced and no preference between juice from control fruit or juice from treated fruit was indicated. At all other rates and application times, apple flavor intensity was enhanced by the use of ETH. Panel scores indicated no difference in liking for juice from apples at the first harvest, regardless of the use of AVG or ETH. At the second harvest, no preference was evident between juice from treated (AVG alone or $\mathrm{AVG}+75$ $\mathrm{mg} \cdot \mathrm{L}^{-1} 2+1 \mathrm{WBH}$ ) or control fruit. However, juice from control fruit was preferred over juice from apples treated with $A V G+150 \mathrm{mg} \cdot \mathrm{L}^{-1}$ ETH 2 WBH or $75 \mathrm{mg} \cdot \mathrm{L}^{-1}$ ETH $2+1 \mathrm{WBH}$ and $150 \mathrm{mg} \cdot \mathrm{L}^{-1} \mathrm{ETH} 1 \mathrm{WBH}$. Apple juice intensity scores were also reduced for juice from these treatments, particularly for juice from apples treated with AVG $+150 \mathrm{mg} \cdot \mathrm{L}^{-1} \mathrm{ETH} 2 \mathrm{WBH}$ before harvest. Panelists indicated the juice to be weak in flavor intensity. At the second harvest, liking scores were similar between treatments except for the juice score from apples treated with $\mathrm{AVG}+150 \mathrm{mg} \cdot \mathrm{L}^{-1} \mathrm{ETH}$ $2 \mathrm{WBH}$, which was reduced when compared to juice from all other treatments.

In 2001, there was little difference in fruit firmness at harvest among treatments (Table 4). Application of ETH following AVG did not reduce firmness at harvest but did increase SSC and SSC to TA ratio. Bioregulator treatments did not affect TA at harvest. Delaying harvest by 2 weeks resulted in decreased flesh firmness and TA and increased SSC and SSC to TA ratio. Apples treated with AVG alone displayed a reduced overall sensory acceptance score when compared to control fruit or fruit treated with a combination of AVG and ETH (Table 4). Only apples with AVG and $300 \mathrm{mg} \cdot \mathrm{L}^{-1}$ ETH applied $2 \mathrm{WBH}$ were considered superior in overall acceptance to control fruit, while apples treated with other combinations of AVG and ETH were rated as similar to control fruit. Sensory flavor scores for apples treated with AVG alone were similar to flavor scores of control apples, but lower than flavor scores for fruit treated with a combination of AVG and ETH. The sensory flavor score for apples treated with AVG plus $300 \mathrm{mg} \cdot \mathrm{L}^{-1} \mathrm{ETH} 2 \mathrm{WBH}$ was superior to control apples. As expected, fruit texture scores were similar between control apples and treated apples either with AVG alone or in combination with ETH. Previous research has indicated thatAVG-treated apples maintain firmness better than nontreated fruit (Beaudry and Jayanty, 2003; Wang and Dilley, 2001). In the present study the whole-apple sensory panel findings reflected the virtual absence of differences in the objective firmness data recorded for these fruit. Firmness loss in apples due to ETH application has been reported in other trials (Drake et al., 2002). In this case AVG followed by ETH did not result in significant sensory texture deterioration at harvest. Delay of harvest permitted additional fruit maturation and resulted in an increase in overall sensory acceptance, flavor and texture scores.

In 2002, the double application of ETH (75 $\left.\mathrm{mg} \cdot \mathrm{L}^{-1}\right)$ resulted in a reduction in flesh firmness at harvest; all other treatments had no effect on flesh firmness (Table 5). AVG alone reduced SSC at harvest while ETH increased SSC.ETH reversed the effect of previous AVG on SSC and SSC to TA ratio at harvest; SSC and SSC to TA ratio values were as high as or higher than the control. TA at harvest was unaffected by bioregulator treatments. Delaying harvest by 2 weeks resulted in reduced flesh firmness and higher SSC and SSC to TA ratio values, while having no detectable effect on TA.

In a second year of consumer panel evaluation of whole apples, fruit treated with AVG were similar to control apples in overall acceptance, flavor and texture scores (Table 5). Overall sensory acceptance and flavor were only enhanced with the use of AVG + the highest ETH rate used $\left(150 \mathrm{mg} \cdot \mathrm{L}^{-1}\right.$ ETH 2 WBH). In most instances, including ETH after AVG enhanced overall sensory acceptance and flavor when compared to apples treated with AVG alone. Delay of harvest again resulted in increased overall sensory acceptance and flavor scores, but did not change sensory texture scores. In the demographics survey before sensory analysis of whole apples, $85 \%$ of consumers indicated that flavor was a critical factor in apple choice and purchase; $72 \%$ indicated texture and $51 \%$ indicated that color was a critical factor in apple choice and purchase. This emphasis on apple flavor by consumers has also been reported in another study (Washington Apple Commission, 2002).

During the second year of this study, AVG alone or a combination of AVG and ETH along with harvest time had a strong influence on starch hydrolysis and firmness after RA and CAstorage (Table 6). At the first harvest, starch content was unaltered by AVG alone. Following AVG with ETH had no effect on starch hydrolysis by the first harvest date except for a slight increase when ETH was applied at the higher concentration the longest interval before harvest (300 $\left.\mathrm{mg} \cdot \mathrm{L}^{-1}, 2 \mathrm{WBH}\right)$. By the second harvest, fruit treated with AVG displayed less starch hydrolysis than control fruit. Adding ETH as a post-AVG treatment stimulated starch hydrolysis so that starch levels were similar to control fruit.

After $60 \mathrm{~d}$ of RA storage, fruit treated with AVG alone were firmer than fruit treated with AVG + ETH regardless of the amount of ETH or time of application, especially at the first harvest (Table 6). By the second harvest, AVG treated fruit were still firmer than fruit treated with $\mathrm{AVG}+300 \mathrm{mg} \cdot \mathrm{L}^{-1} \mathrm{ETH}$, regardless of time of application, but equivalent in firmness to fruit treated with AVG plus ETH at the lower concentration. In all cases, treatment with AVG resulted in firmer fruit than controls, with or without ETH. In CA storage (120 d), fruit treated with AVG alone were only firmer than fruit treated with $\mathrm{AVG}+300 \mathrm{mg} \cdot \mathrm{L}^{-1} \mathrm{ETH}$ at (2 WBH). Again, nearly all AVG treatments maintained flesh firmness better than control fruit. Regardless of treatment, firmness of all fruit (60 RA, $120 \mathrm{CA}$ ) met or exceeded Washington State grade standards. After 180 $\mathrm{d}$ of CA storage, AVG alone and AVG + ETH treated apples were similar in firmness (66 to $68 \mathrm{~N})$ and firmer $(59.8 \mathrm{~N})$ than control apples when harvested early. If harvest was delayed 2 weeks, only AVG and AVG + ETH at 150 $\mathrm{mg} \cdot \mathrm{L}^{-1}$ met or exceeded Washington State grade standards $(53.4 \mathrm{~N})$ for firmness after 180 $\mathrm{d}$ of CA storage. Late-harvested control fruit and any fruit treated with AVG + ETH at 300 $\mathrm{mg} \cdot \mathrm{L}^{-1}$ failed to meet grade standards.

AVG application did not influence the

Table 8. Effects of aminoethoxyvinylglycine (AVG) applied alone or sequentially with ethephon (ETH) on fruit internal ethylene concentration (IEC) and watercore incidence in 'Delicious' (Scarletspur strain) apples at harvest and after regular (RA) or controlled atmosphere (CA) storage (Trial 3, 2001).

\begin{tabular}{|c|c|c|c|c|c|c|c|}
\hline & \multicolumn{2}{|c|}{ At harvest } & \multicolumn{2}{|c|}{$\mathrm{RA}(60 \mathrm{~d})$} & \multicolumn{2}{|c|}{$\mathrm{CA}(120 \mathrm{~d})$} & \multirow{2}{*}{$\begin{array}{c}\mathrm{CA}(180 \mathrm{~d}) \\
\mathrm{IEC} \\
\left(\mathrm{mg} \cdot \mathrm{L}^{-1}\right)\end{array}$} \\
\hline & $\begin{array}{c}\mathrm{IEC} \\
\left(\mathrm{mg} \cdot \mathrm{L}^{-1}\right)\end{array}$ & $\begin{array}{c}\text { Watercore } \\
(\%)\end{array}$ & $\begin{array}{c}\text { IEC } \\
\left(\mathrm{mg} \cdot \mathrm{L}^{-1}\right)\end{array}$ & $\begin{array}{c}\text { Watercore } \\
(\%)\end{array}$ & $\begin{array}{c}\mathrm{IEC} \\
\left(\mathrm{mg} \cdot \mathrm{L}^{-1}\right)\end{array}$ & $\begin{array}{c}\text { Watercore } \\
(\%)\end{array}$ & \\
\hline \multicolumn{8}{|l|}{ Bioregulator } \\
\hline Control & $2.9 \mathrm{a}^{\mathrm{z}}$ & $8.0 \mathrm{a}$ & $39.0 \mathrm{a}$ & $12.0 \mathrm{ab}$ & $15.2 \mathrm{a}$ & $9.0 \mathrm{ab}$ & $20.2 \mathrm{a}$ \\
\hline AVG $125 \mathrm{mg} \cdot \mathrm{L}^{-1}(4 \mathrm{WBH})^{\mathrm{y}}$ & $0.2 \mathrm{~b}$ & $3.0 \mathrm{a}$ & $2.5 \mathrm{~b}$ & $4.0 \mathrm{~b}$ & $3.3 \mathrm{~b}$ & $0.0 \mathrm{~b}$ & $4.6 \mathrm{~b}$ \\
\hline $\mathrm{AVG}+\mathrm{ETH} 150 \mathrm{mg} \cdot \mathrm{L}^{-1}(2 \mathrm{WBH})^{\mathrm{x}}$ & $0.3 \mathrm{~b}$ & $13.0 \mathrm{a}$ & $5.0 \mathrm{~b}$ & $28.0 \mathrm{a}$ & $2.7 \mathrm{~b}$ & $25.0 \mathrm{a}$ & $4.4 \mathrm{~b}$ \\
\hline $\mathrm{AVG}+\mathrm{ETH} 300 \mathrm{mg} \cdot \mathrm{L}^{-1}(2 \mathrm{WBH})^{x}$ & $0.7 \mathrm{~b}$ & $10.0 \mathrm{a}$ & $4.1 \mathrm{~b}$ & $23.0 \mathrm{a}$ & $2.7 \mathrm{~b}$ & $14.0 \mathrm{ab}$ & $2.5 \mathrm{~b}$ \\
\hline $\mathrm{AVG}+\mathrm{ETH} 150 \mathrm{mg} \cdot \mathrm{L}^{-1}(1 \mathrm{WBH})^{\mathrm{w}}$ & $0.3 \mathrm{~b}$ & $7.0 \mathrm{a}$ & $4.8 \mathrm{~b}$ & $19.0 \mathrm{a}$ & $1.9 \mathrm{~b}$ & $20.0 \mathrm{a}$ & $2.3 \mathrm{~b}$ \\
\hline $\mathrm{AVG}+\mathrm{ETH} 300 \mathrm{mg} \cdot \mathrm{L}^{-1}(1 \mathrm{WBH})^{\mathrm{w}}$ & $0.3 \mathrm{~b}$ & $12.5 \mathrm{a}$ & $5.7 \mathrm{~b}$ & $18.5 \mathrm{a}$ & $3.9 \mathrm{~b}$ & $18.0 \mathrm{a}$ & $3.6 \mathrm{~b}$ \\
\hline \multicolumn{8}{|l|}{ Harvest } \\
\hline I & $0.2 \mathrm{~b}$ & $0.0 \mathrm{~b}$ & $5.6 \mathrm{~b}$ & $0.0 \mathrm{~b}$ & $2.4 \mathrm{~b}$ & $0.0 \mathrm{~b}$ & $5.1 \mathrm{~b}$ \\
\hline II & $1.4 \mathrm{a}$ & $8.3 \mathrm{a}$ & $14.7 \mathrm{a}$ & $17.5 \mathrm{a}$ & $7.5 \mathrm{a}$ & $14.3 \mathrm{a}$ & $7.5 \mathrm{a}$ \\
\hline Bioregulator $\times$ harvest & NS & NS & NS & NS & NS & NS & NS \\
\hline
\end{tabular}

${ }^{\mathrm{z}}$ Means in a column not followed by a common letter are significantly different $(P \leq 0.05)$.

${ }^{y} \mathrm{AVG}$ applied 4 weeks before first harvest.

${ }^{x} \mathrm{AVG}$ applied at $125 \mathrm{mg} \cdot \mathrm{L}^{-1} 4$ weeks before first harvest followed by ETH at 150 or $300 \mathrm{mg} \cdot \mathrm{L}^{-1} 2$ weeks before first harvest.

wAVG applied at $125 \mathrm{mg} \cdot \mathrm{L}^{-1} 4$ weeks before first harvest followed by ETH at 150 or $300 \mathrm{mg} \cdot \mathrm{L}^{-1} 1$ week before first harvest.

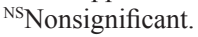


peel color of 'Delicious' (Scarletspur strain) apples after $60 \mathrm{~d}$ of RA storage or $120 \mathrm{~d}$ of CA storage, regardless of harvest time (Table 7). After $180 \mathrm{~d}$ of CA storage, AVG treated fruit displayed redder (lower hue) peel color than control fruit from both harvest, but only at this storage duration. Use of AVG + ETH (150 or $300 \mathrm{mg} \cdot \mathrm{L}^{-1}$ ) produced darker (lower L values), redder (lower hue value) apples than controls at all storage times, but only when apples were harvested early. By the second harvest, no bioregulator treatment affected peel color after $180 \mathrm{~d}$ CA storage.

AVG treatment reduced IEC compared to control fruit at harvest and after all storage times, regardless of fruit harvest date (Table 8). Application of ETH following AVG treatment did not overcome the AVG-based control over fruit ethylene production, even after 180 $\mathrm{d}$ in CA. IEC was higher for fruit harvested on the second harvest date, but the relationship of fruit IEC to treatments remained the same. At both harvests, the amount of watercore present was similar regardless of the amount of ETH applied. After $60 \mathrm{~d}$ of RA storage, apples treated with AVG displayed significantly less watercore than apples treated with $\mathrm{AVG}+\mathrm{ETH}$, regardless of the amount ofETH applied. AVG + ETH treated apples displayed watercore at a similar level as control apples. These differences in watercore were also evident after 120 d of CA storage. After $180 \mathrm{~d}$ of CA storage, apples treated with $\mathrm{AVG}+\mathrm{ETH}$ at $150 \mathrm{mg} \cdot \mathrm{L}^{-1}$ (1 WBH) showed more watercore than all other treatments, which were the same.

\section{Conclusions}

AVG and ETH are both tools used to manipulate fruit maturity and quality; AVG delays the changes associated with maturity and ripening while ETH accelerates those changes. In this study AVG delayed fruit maturity and flesh firmness loss, but reduced flavor. ETH reduced flesh firmness but aided flavor development. Because following AVG-treated fruit with ETH before harvest did not stimulate uncontrolled fruit ethylene evolution, combination treatments of AVG and ETH produced fruit with improved flavor and texture retention even after short or long-term storage. Using AVG and ETH overcame the disadvantages of either product when used alone. Fruit quality was best at harvest and after storage with a combination of both AVG and ETH.

Fruit continue to mature and ripen until harvested. In this study, quality attributes (objective and subjective) were superior for all treatments at harvest I (commercial) versus harvest II (2-week delay). Earlier-harvested fruit showed less water core, better firmness and better flavor, liking and preference scores. This harvest-date effect on fruit quality continued through both RA and CA storage. AVG treatment alone produced apples with optimum objectively measured characteristics but not the best flavor quality in all 3 years. ETH applied at $300 \mathrm{mg} \cdot \mathrm{L}^{-1}$ reduced subjective perception quality scores, particularly for texture; this concentration was probably too high for this cultivar. The results of this study suggest that preharvest AVG followed by ETH at $2 \mathrm{WBH}$ applied to fruit harvested at the commercial harvest date may be the best approach for optimizing all quality attributes, both objective and subjective, while maintaining long-term storability.

\section{Literature Cited}

Andrews P.K. 2001. Gala splitting. Proc. Wash. Tree Fruit Postharvest Conf., 13-14 Mar., Wenatchee.

Bangerth, F. 1978. The effect of a substituted amino acid on ethylene biosynthesis, respiration, ripening and preharvest drop of apple fruits. J. Amer. Soc. Hort. Sci. 103:401-404.

Beaudry, R. and S. Jayanty. 2003. Improving McIntosh storability: Amarriage of ReTain and SmartFresh. The Fruit Growers News 42:38-39.

Blanpied, G.D. 1972. A study of ethylene in apple, red raspberry and cherry. Plant Physiol. 49:627-630

Byers, R.E. 1997. Effects of aminoethoxyvinylglycine (AVG) on preharvest drop, maturity, and cracking of several apple cultivars. J.Tree Fruit Prod. 2:77-97.

Drake, M.A., S.R. Drake, D.C. Elfving, and T. A. Eisele. 2002. Influence of bioregulators on apple fruit quality. Proc. Inst. Food Technologists Annu. Mtg., 15-19 June, Anaheim, Calif.

Drake, S.R., D.C. Elfving, T.A. Eisele, M.A. Drake, S.L. Drake, and D.B. Visser. 2003. Effects of ethephon and aminoethoxyvinylglycine on the carbohydrate and acids contents of 'Delicious' (Scarletspur strain) apples (Malus domestica Borkh.). Proc. Inst. Food Technologists Annu. Mtg., 12-16 July, Chicago, Ill.

Drake, S.R., T.A. Eisele, D.C. Elfving, M.A. Drake, S.L. Drake, and D.B. Visser. 2005. Effects of the bioregulators aminoethoxyvinylglycine and ethephon on brix, carbohydrate, acid and mineral concentrations in 'Scarletspur Delicious' apple juice. HortScience (in press).

Edgerton, L.J. and G.D. Blanpied. 1968. Regulation of growth and fruit maturation with 2-chloroethanephosphonic acid. Nature 219:1064-1065.

Elfving, D.C. and R.A. Cline. 1990. Effects of annually applied growth control techniques on growth and productivity of vigorous 'Northern Spy'MM.106 apple trees. J. Amer. Soc. Hort.
Sci. $115: 212-218$

Elfving, D.C., G.A. Lang and D.B. Visser. 2003. Prohexadione-Ca and ethephon reduce shoot growth and increase flowering in young, vigorous sweet cherry trees. HortScience 38:293-298.

Greene, D.W., J. Krupa, and J. Clements. 2000. Effects of simulated rain following ReTain application on preharvest drop and fruit quality of McIntosh apples. Fruit Notes 60:57-60.

Greene, D.W. 2002. Preharvest drop control and maturity of 'Delicious' apples as affected by aminoethoxyvinylglycine (AVG). J. Tree Fruit Prod. 3:1-10.

Halder-Doll, H. and F. Bangerth. 1987. Inhibition of autocatalytic $\mathrm{C} 2 \mathrm{H} 4$ biosynthesis of AVG applications and consequences on the physiological behavior and quality of apples fruits in cool storage. Scientia Hort. 33:87-96.

Hunter, R.S. and R.W. Harold. 1987. The measurement of appearance. 2nd ed. Wiley, N.Y.

Layne, D.R., J. Zhengwang, and J.W. Rushing. 2002. The influence of reflective film and ReTain on red skin coloration and maturity of 'Gala' apples. HortTechnology 12:640-645.

Larrigaudiere, C., E. Pinto, and M. Vendrell. 1996. Differential effects of ethephon and seniphon on color development of 'Starking Delicious' apple. J. Amer. Soc. Hort. Sci. 121:746-750.

Looney, N. 2004. Plant growth regulators will still be needed. Good Fruit Grower. 55:14-15.

Meilgaard, M.M., G.V. Civille, and B.T. Carr. 1999. Affective tests: Consumer tests and in-house panel acceptance test, p. 231-263. In: Sensory evaluation techniques. 3rd ed. CRC Press, Boca Raton, Fla.

Stover, E., J.J. Fargione, C.B. Watkins, and K.A. Iungerman. 2003. Harvest management of 'Marshall McIntosh' apples: Effects of ethephon, and summer pruning on preharvest and fruit. HortScience 38:1093-1099.

Wang, Z. and D.R. Dilley. 2001.Aminoethoxyvinylglycine, combined with ethephon, can enhance red color development without over-ripening apples. HortScience 36:328-331.

Washington Agriculture Code. 1990. 16-403-142. Washington inspection procedures. $15 \mathrm{Jan} .1990$. Wash. Agriculture Code.

Washington Apple Commission. 2002. Red Delicious analysis report. TRD Frameworks, 8 May 2002.

Washington Apple Maturity Program. 1993. Washington apple maturity handbook. 1993. Wash. Apple Maturity Progr., Wenatchee.

Watkins, C.B. and D.A. Rosenberger. 1999. Items of interest for storage operators in New York and beyond. Cornell Fruit Handling Storage Nwsltt.

Williams, M.W. 1980. Retention of fruit firmness and increase in vegetative growth and fruit set of apples with aminoethoxyvinylglycine. HortScience 15:76-77.

Yang, S.F. 1969. Ethylene evolution from 2chloroethylphosphonic acid. Plant Physiol. 44:1203-1204. 